\title{
Destructive Federal Preemption of State Wealth Transfer Law in Beneficiary Designation Cases: Hillman Doubles Down on Egelhoff
}

\begin{abstract}
John H. Langbein*
The probate codes in about a third of the states contain a so-called divorce revocation provision, applicable both to probate and nonprobate transfers. Such statutes address the situation in which a transferor's will or will substitute designates as a beneficiary a person who was the transferor's spouse at the time that the transferor executed the document, but whom the transferor later divorced. The premise of these statutes is that divorce entails a profound change of circumstances not foreseen by the transferor, and that the transferor is unlikely to have intended to benefit an ex-spouse. Accordingly, the intentimplementing purpose of wealth transfer law is better served by having a default rule that treats the subsequent divorce as having revoked any provision for the now-ex-spouse unless the document expressly provides otherwise.

In Egelhoff v. Egelhoff (2001), the Supreme Court held that when the instrument of transfer is a beneficiary designation in a pension plan or life insurance policy subject to federal regulation under the Employee Retirement Income Security Act ("ERISA"), the otherwise applicable state divorce revocation statute is preempted, even though ERISA makes no mention of divorce revocation. The Court reasoned that enforcing the state divorce revocation statute would "interfere with nationally uniform plan administration."

Because the result in Egelhoff allowed supposed plan-level administrative convenience to defeat the principled objective of the divorce revocation statutes, a number of courts reacted by allowing so-called post-

* Sterling Professor of Law and Legal History, Yale University. This article refers to provisions of the Restatement (Third) of Property: Wills and Other Donative Transfers (19992011) and the Uniform Probate Code (1989-90 rev.) ("UPC"). I served as Associate Reporter for the Restatement and as a member of the drafting committees that revised the UPC, but the views expressed here are not voiced on behalf of the American Law Institute or the Uniform Law Commission. I acknowledge with gratitude suggestion sfom William Eskridge, Albert Feuer, Abbe Gluck, Robert Sitkoff, Stewart Sterk, Lawrence W. Waggoner, and Edward Zelinsky.
\end{abstract}


distribution relief, in some cases pursuant to a state statute so providing. Obeying Egelhoff, these courts preempted the state divorce revocation law at the plan level, thereby permitting the ex-spouse to receive the designated benefit from the plan, but allowing the person(s) entitled under the divorce revocation statute to recover those proceeds from the ex-spouse in a subsequent state-court action based on unjust enrichment. In a 2013 decision, Hillman v. Maretta, involving an insurance policy purchased under a program for federal employees, the Supreme Court extended preemption to forbid such postdistribution relief.

In this Article, I point to serious shortcomings in the reasoning and policy merits of Egelhoff and Hillman. There is no federal policy favoring wealth transfer to ex-spouses. The divorce revocation statutes exemplify the core policy value of state wealth transfer law, which is to implement the transferor's intent, a policy distinct from and congruent with the purposes of the federal statutes on which the Court based preemption in the two cases. Unless Congress intervenes or unless the Court permits the development of a federal common law of divorce revocation, Egelhoff and Hillman will saddle American wealth transfer law with needlessly contradictory federal and state rules, sometimes applicable to different transfers by the same transferor.

I. INTRODUCTION ............................................. 1666

II. DIVORCE REVOCATION......................................... 1668

III. PREEMPTION: EGELHOFF .................................... 1671

IV. POST-PREEMPTION PREEMPTION .............................. 1678

A. Post-Distribution Relief ................................ 1678

B. Hillman ..................................................... 1681

C. Wissner and Ridgway ............................... 1684

V. THE SLAYER BENEFICIARY AND THE IMPULSE TO FEDERAL COMMON LAW ................................................. 1688

VI. CONCLUSION ..................................................... 1694

\section{INTRODUCTION}

In a pair of decisions rendered a dozen years apart concerning beneficiary designations in financial accounts that pass wealth on death, Hillman v. Maretta (2013) ${ }^{1}$ and Egelhoff v. Egelhoff (2001), ${ }^{2}$ the U.S. Supreme Court has managed to get itself on the wrong side of two great social and demographic trends. One is the spread of divorce. Couples are no longer locked into failed marriages, and the divorce rate

1. 133 S. Ct. 1943 (2013).

2. 532 U.S. 141 (2001). 
now exceeds forty percent. ${ }^{3}$ The other great trend is the transformation in the patterns of wealth transmission on death known as the nonprobate revolution, ${ }^{4}$ that is, the increasing tendency to transfer wealth by means of beneficiary designations in accounts administered by financial intermediaries such as life insurance companies, banks, investment companies, pension plans, and trust companies. ${ }^{5}$ These nonprobate modes of transfer have become so pervasive that, in the affairs of many (probably now most) decedents, more wealth passes by means of financial-account beneficiary designations than by will or intestacy in the traditional probate process. ${ }^{6}$

In the American system of dual federal and state jurisdiction, state law governs the process of wealth transfer on death, typically under comprehensive legislation that, although commonly called the probate code, also covers nonprobate transfers. ${ }^{7}$ Because probate and nonprobate transfers have the same purpose, transferring the decedent's wealth to his or her intended beneficiaries, the modern codes

3. "For the average couple marrying for the first time in recent years, the lifetime probability of divorce or separation now falls between 40 and 50 percent." UNIV. OF VA., THE NAT'L MARRIAGE Project, The State of OUR Unions: MARRIAGe IN 2012, at 67 (2012). Regarding the background, see, e.g., Mary Ann Glendon, The Transformation of Family LaW: State, LaW, and Fayily in the United States and Western Europe (1989); Herbert Jacob, Silent Revolution: The Transformation of Divorce LaW in the United States (1988); W. Bradford Wilcox, The Evolution of Divorce, 1 NAT'L AFF. 81 (2009).

4. See, e.g., Susan N. Gary, Transfer-on-Death Deeds: The Nonprobate Revolution Continues, 41 Real Prop. Prob. \& TR. J. 529 (2006); John H. Langbein, The Nonprobate Revolution and the Future of the Law of Succession, 97 HARV. L. REV. 1108 (1984).

5. The typical beneficiary designation takes the juridical form of a contract term in an account with a financial intermediary. See UNIF. PROBATE CODE $\$$ 6-101 ("UPC") (identifying and validating a wide range of mostly contract-based will substitutes). For the carriage trade, the revocable trust is the characteristic nonprobate device. The Uniform Trust Code "treat[s] the revocable trust as the functional equivalent of a will." UNIF. TRUST CODE art. 6, gen. cmt. In many states the owner of an interest in real property may now transfer it by means of a beneficiary designation; regarding which, see Gary, supra note 4 . A recently promulgated uniform act is likely to facilitate the spread of such transfers. UNIF. REAL PROP. TRANSFER ON DEATH ACT (2009) (codified at UPC art. 6, pt. 4).

6. For recent data on the asset magnitudes of the main will substitutes, see John $\mathrm{H}$. Langbein, Major Reforms of the Property Restatement and the Uniform Probate Code: Reformation, Harmless Error, and Nonprobate Transfers, 38 ACTEC L.J. 1, 12-14 (2012). There has been a pronounced trend in the private pension system over the past generation toward individual account plans - that is, defined contribution plans and individual retirement accounts. Regarding the causes and consequences, see, e.g., Edward A. Zelinsky, The Defined Contribution Paradigm, 114 YALE L.J. 451 (2004). This trend has greatly increased the number of pension accounts in which the account holder dies with a transferable balance in the account. Beneficiary designations govern the proceeds in such accounts. In a defined benefit plan, by contrast, annuitization is the prevalent mode of distribution. The plan pays a lifetime benefit that ceases on the death of the survivor of the participant and his or her spouse, and there is no account balance on death.

7. For example, the Uniform Probate Code, which is primarily concerned with probate transfers, governs various aspects of nonprobate transfers in Article II, Part 8, and in Article VI. 
strive to unify the field by applying common constructional principles to both. ${ }^{8}$

\section{DIVORCE REVOCATION}

The intersection of liberalized divorce with the world of nonprobate transfers occurs in consequence of a recurrent situation. John and Mary are spouses. While married, John executes a beneficiary designation form governing a financial account, say a life insurance policy or a retirement plan, naming Mary as the death beneficiary if she survives him. Under the contract with the financial intermediary that creates the account, John, the account owner, may revoke the beneficiary designation at any time until his death, usually by substituting a different beneficiary. Some time after John names Mary as his beneficiary, often years later, the marriage sours, and John and Mary divorce. John, not thinking about the implications of the divorce for this transfer-on-death designation, neglects to update it. Subsequently, John dies, having left in force the pre-divorce designation that names Mary, now his ex-spouse, to take the account proceeds. ${ }^{9}$ Cases of this sort are less likely to occur among affluent persons who, when they divorce, are commonly represented by specialist legal counsel, whose job includes prompting clients to review and update estate planning documents. Thus, these cases of stale spousal

8. See, e.g, UPC art. II, prefatory note (discussing the objective to "bring the law of probate and nonprobate transfers into greater unison"). See generally Grayson M.P. McCouch, Probate Law Reform and Nonprobate Transfers, 62 U. MLAMI L. REV. 757 (2008).

9. Regarding the causes of such oversight, bear in mind that "[i]t is not uncommon for a propertied person to have a dozen or more will-like beneficiary designations in effect on various banking, investment, insurance, and pension accounts." Langbein, supra note 6, at 12 . For evidence that account holders sometimes lose track of such accounts, see Langbein, supra note 4, at 1109-10 n.3. Sterk and Leslie point out that beneficiary designations on employer-provided pension, savings, and insurance accounts are commonly executed in connection with initial employment paperwork, when wealth transfer on death "is far from the employee's mind .... [Thereafter, employees] may not look again at those forms for decades; many will have no idea whom they designated as beneficiaries, and no idea how to find out." Stewart E. Sterk \& Melanie B. Leslie, Accidental Inheritance: Retirement Accounts and the Hidden Law of Succession, 89 N.Y.U. L. REV. 154, 167-68 (2014). An expert advisory panel examining ERISA beneficiary designation problems concluded in a 2012 report to the Department of Labor (the agency charged with overseeing the operation of ERISA) that this potential for a beneficiary designation form to "remain on file for a very long time, sometimes decades, without review ... increases the likelihood that the original designation may not reflect the [transferor's] current intent." ADVISORY COUNCIL on Employee Welfare \& Pension Benefit Plans, Current Challenges and Best Practices CONCERNING BENEFICIARY DESigNATIONS In RETIREMENT AND Life InSURANCE Plans 4 (2012), available at www.dol.goc/ebsa/pdf/2012ACreport1.pdf, archived at http://perma.cc/45ZF-WW59. The report found that "[t]he most common and frequently contentious disputes [arising from ERISA beneficiary designations] occur where participants marry or divorce but fail to update their beneficiary designations to reflect this change of status before their death." Id. at 3 . 
beneficiary designations arise mostly among persons of modest means-persons who, when they divorce, do not find their way to expert counsel, or indeed, to any counsel. ${ }^{10}$

Sixteen American states address cases of this sort in their probate codes by means of what is called a divorce revocation statute, applicable both to probate and nonprobate transfers. ${ }^{11}$ The statutes provide as a default rule that a subsequent divorce revokes any predivorce provision for the ex-spouse. ${ }^{12}$ This divorce revocation rule originated in the law of wills and was extended to financial-account beneficiary designations as their use spread. ${ }^{13}$ What motivates the rule is the understanding that divorce commonly entails a sufficiently traumatic breach in the relations of the former spouses that they are not likely thereafter to intend to benefit each other by means of wealth transfer on death. ${ }^{14}$ Moreover, divorce commonly entails a lifetime division of the former spouses' property, which supersedes estate planning objectives previously formulated during the marriage. ${ }^{15}$ Accordingly, what John really meant when he designated Mary as the beneficiary is that he intended Mary to take on the condition that they remained married. A rule imputing that condition will reflect the

10. Offers of do-it-yourself divorce kits abound on the internet. See, e.g., Do It Yourself Divorce, QUICK-DIVORCE.COM, http://www.quick-divorce.com/index.htm, archived at http:/l perma.cc/3UHB-7FUY (last visited Sept. 6, 2014).

11. Divorce revocation laws extending to nonprobate transfers, mostly derived from Uniform Probate Code $\S 2-804$, are in force in Alaska, Arizona, California, Hawaii, Maine, Massachusetts, Michigan, Minnesota, Montana, New Mexico, New York, North Dakota, South Dakota, Utah, Virginia, and Washington. For references to the statutes, see EUNICE L. ROSs \& THOMAS J. REED, Will Contests $\$ 5: 19$ (2d ed. 2011); Restatement (Third) of Property: WLLS and Other DOnative Transfers \$ 4.1(b) statutory notes 2(b)-(c) (1999) ("Property RestatemenT").

12. The statutes treat the ex-spouse as though he or she disclaimed the interest passing under the beneficiary designation, e.g., UPC $\$ 2-804(\mathrm{~d})$; or as though the ex-spouse predeceased the decedent, e.g., WASH. REV. CODE $\$ 11.07 .010$ (2)(a) (1994), which was the provision at issue in Egelhoff $v$. Egelhoff, 532 U.S. 141, 143 (2001). In either case the ex-spouse's interest lapses, and the lapsed interest passes to the next contingent taker named in the beneficiary designation or in the account's default terms. In the rare case in which the account identifies no such alternative taker, the asset would pass with the decedent's probate estate. See, e.g., UPC $\$ 2-101$ (a).

13. See Lawrence W. Waggoner, The Multiple-Marriage Society and Spousal Rights Under the Revised Uniform Probate Code, 76 IOWA L. REV. 223, 227-28 (1991).

14. "Divorce usually represents a stormy parting, where the last thing one of the parties wishes is to have an earlier will carried out giving everything to the former spouse." Raymond $\mathrm{H}$. Young, Probate Reform, 18 Bos. B.J. 7, 11 (1974), quoted with approval in Clymer v. Mayo, 473 N.E.2d 1084, 1092 (Mass. 1985).

15. A point emphasized by Justice Breyer in his dissent in Egelhoff, in which he observed that by defeating the operation of the divorce revocation statute at issue in that case, "the Court permits a divorced wife, who already acquired, during the divorce proceeding, her fair share of the couple's community property, to receive in addition the benefits that the divorce court awarded to her former husband." 532 U.S. at 159. 
intention of the typical decedent much more often than not. ${ }^{16}$ In keeping with the intent-implementing purpose, divorce revocation statutes invariably take the form of a default rule that the transferor may defeat, ${ }^{17}$ either by inserting a term in the beneficiary designation countermanding the rule, or by executing a post-divorce beneficiary designation in favor of the former spouse.

The intent-implementing purpose of the divorce revocation statutes is an expression of the dominant policy of American wealth transfer law, which is to give effect to the intention of the transferor. ${ }^{18}$ This principle governs the interpretation of beneficiary designations. The Restatement (Third) of Property says: "The controlling consideration in determining the meaning of a donative document is the donor's intention." 19 Both the Uniform Probate Code ${ }^{20}$ and the Restatement ${ }^{21}$ codify the divorce revocation rule. Although the rule is in force in only a minority of the states, ${ }^{22}$ no state has legislation mandating a contrary result. Thus, the divorce revocation rule is universally preferred in the statute law of every state in which the legislature has addressed the question of whether a transferor is likely to have intended a spousal beneficiary designation to remain in effect in the event the parties subsequently divorce. ${ }^{23}$

Astonishingly, however, in Hillman and Egelhoff the Supreme Court suppressed the state divorce revocation statutes and ordered the account property to pass to the ex-spouse under the beneficiary designation that the deceased spouse had executed before the marriage dissolved. In neither case did the Court deny or even discuss the policy

16. In the law of donative transfers, "[t]he foundational constructional preference is for the construction that is more in accord with common intention than other plausible constructions." PROPERTY RESTATEMENT, supra note $11, \S 11.3(\mathrm{c})$.

17. For example, the operative provision of the Uniform Probate Code version commences with the proviso that divorce revocation pertains "[e]xcept as provided by the express terms of" the beneficiary designation or other governing instrument. UPC § 2-804(b).

18. Property Restatement, supra note $11, \S 10.1$.

19. Id.

20. UPC $\$ 2-804$

21. Property Restatement, supra note 11, $\$$ 4.1(b) ('The dissolution of the testator's marriage is a change in circumstance that presumptively revokes any provision in the testator's will in favor of his or her former spouse.").

22. For cases refusing to apply the divorce-revocation rule to insurance contracts in the absence of a statute, see Kristen P. Raymond, Note, Double Trouble-An Ex-Spouse's Life Insurance Beneficiary Status and State Automatic Revocation upon Divorce Statutes: Who Gets What?, 19 CONN. INS. L.J. 399, 407 n.35 (2013).

23. States that have enacted such a rule are listed supra note 11. In Massachusetts, when the express terms of the state divorce-revocation rule still addressed only wills, the Supreme Judicial Court extended the rule to nonprobate transfers by trust. See Clymer v. Mayo, 473 N.E.2d 1084, 1093 (Mass. 1985). Massachusetts has since adopted the Uniform Probate Code provision. See MASs. GEN. LAwS ANN. ch. 190B, § 2-803 (2014). 
merits of the divorce revocation rule. Rather, the Court held that, because the beneficiary designations in question were found in financial accounts authorized or regulated under federal statutes, federal law preempted the state divorce revocation statutes, even though the federal statutes were wholly silent about divorce revocation.

\section{PREEMPTION: EGELHOFF}

The entanglement of federal law and federal courts with nonprobate wealth transfer, and the consequent potential for preemption of the state-law rules that commonly govern the field, arise in circumstances in which federal law creates or regulates financial accounts that authorize beneficiary designations. Hillman concerned a beneficiary designation on a life insurance policy issued under a congressionally established benefit program for federal employees. ${ }^{24}$ The accounts in Egelhoff were found in private-sector employee benefit plans that were federally regulated under the Employee Retirement Income Security Act ("ERISA"). ${ }^{25}$ In such cases, from the standpoint of wealth transfer law, the federal law is fragmentary. Federal law touches the wealth transfer field to the extent of regulating or facilitating the creation of financial accounts that contain beneficiary designations, but the federal law does not concern itself with the recurrent constructional complications that arise in the wealth transfer process-matters that are addressed comprehensively in the state probate codes and state decisional law. There is no doubt that, under the Supremacy Clause of the Constitution, ${ }^{26}$ Congress has the power to forbid the application of state wealth transfer law to a federally authorized account. The question that arose in Egelhoff and Hillman was whether Congress had done so by implication from accountcreating or account-regulating federal statutes that do not even mention the relevant provision of state wealth transfer law, here divorce revocation.

Egelhoff ${ }^{27}$ concerned beneficiary designations on two employerprovided accounts, a pension plan and a group life insurance policy. ${ }^{28}$

\footnotetext{
24. See infra text accompanying note 86 .

25. 29 U.S.C. $\$ 1001$ et seq. (2012).

26. U.S. CONST. art. VI, $\$ 2$.

27. 532 U.S 141 (2001).

28. Group life insurance is a characteristic employee benefit. An employer or an entity such as a labor union or a professional association contracts with an insurer to make insurance available to all members of the particular workforce or other group. Group insurance is commonly less costly than comparable coverage under individually purchased policies, because insuring an entire workforce spares the transaction costs and adverse selection risks associated with the sale and underwriting of individual policies. In the United States as of 2011, group insurance constituted
} 
David Egelhoff owned the accounts through his employment with Boeing, the aerospace firm. David designated his wife Donna as the death beneficiary on both accounts. David and Donna, who were domiciliaries of Washington State, subsequently divorced. Two months later, David died in an automobile accident without having revoked the beneficiary designations to Donna. Pursuant to those designations, Donna collected the life insurance proceeds and also claimed the pension benefit. David's children by a former marriage, who would have been entitled to both accounts under Washington's divorce revocation law, ${ }^{29}$ sued Donna in state court to recover the insurance proceeds and to establish their right to the pension account. Donna defended on the ground that, because both accounts constituted interests in employee benefit plans that were federally regulated under ERISA, ERISA preempted the Washington divorce revocation statute.

ERISA subjects private-sector employee benefit plans to a variety of requirements designed to protect plan participants and beneficiaries against the loss or forfeiture of promised benefits. ${ }^{30}$ The act imposes funding, benefit accrual, and vesting requirements on pension plans, and it requires defined benefit pension plans to participate in a federally administered insurance program, modeled on the Federal Deposit Insurance Corporation for banks, that will pay most plan-promised benefits in the event of default. Further, ERISA subjects all covered plans to reporting and disclosure obligations, and to fiduciary standards for investing plan assets and administering plan affairs. ${ }^{31}$ In keeping with ERISA's central concern to prevent abuses

thirty-nine percent of all life insurance in force, amounting to $\$ 8.1$ trillion in coverage. AM. COUNCIL OF LIFE INSURERS, LIFE INSURERS FACT BOOK 2012, at 65 (2012). The group life program for federal employees that was involved in Hillman v. Maretta, discussed infra in text accompanying note 84, was a contract with the Metropolitan Life Insurance company under which the total amount of insurance in force as of 2010 was $\$ 824$ billion. $133 \mathrm{~S}$. Ct. 1943, 1947 (2013) (citing U.S. Gov't ACCOUNTABIlity OfFiCe, GAO-12-94, Federal Employees' Group Life Insurance: Retirement BenEFit and Retained Asset ACCount Disclosures Could Be IMPROVED 1 (2011)).

29. See WASH. REV. CODE $\$ 11.07 .010$ (2)(a) (1994), revoking any pre-divorce provision for a spouse "in a nonprobate asset," defined in $\$ 11.07 .010(5)(a)$ to include "a life insurance policy, employee benefit plan, annuity or similar contract, or individual retirement account."

30. See John H. Langbein, Davit Pratt \& Susan Stabile, Pension and Employee Benefit LAW 146-47 (5th ed. 2010) (identifying agency risk, default risk, and forfeiture risk as the principal concerns to which ERISA was directed). Regarding the origins and objectives of ERISA, see JAMES A. Wooten, THe Employee Retirement Income SECurity ACt of 1974: A Political History (2004); Michael S. Gordon, "Overview: Why Was ERISA Enacted?" in U.S. Senate, Special Comm. on Aging: The Employee Retirement InCome Security ACt of 1974: The First Decade 6-25 (1984).

31. For surveys of ERISA fiduciary law, see, e.g., PETER J. WIEDENBECK, ERISA: PRINCIPLES of Employee Benefit LAW 109-53 (2010); LAngBein, PRATt \& Stabile, supra note 30, at 541747. 
that would defeat the reliance of plan participants and beneficiaries upon promised benefits, the statute contains language, emphasized by the Court in Egelhoff, ${ }^{32}$ requiring that the terms of any ERISA-covered plan "specify the basis on which payments are made to and from the plan"; 33 and requiring the plan administrator to administer the plan "in accordance with the documents and instruments governing the plan." 34 The two beneficiary designations in which David named Donna were executed in compliance with such ERISA plan terms.

ERISA contains a broadly worded preemption clause that "supersede[s]" state laws that "relate to" any ERISA-covered plan. ${ }^{35}$ After a troubled early case law, ${ }^{36}$ the Supreme Court has come to interpret the "relate to" standard as balancing the interests of state law with the purposes of ERISA. ${ }^{37}$ The question in Egelhoff was whether ERISA's preemption clause "supersede[d]" Washington's divorce revocation statute. The Washington Supreme Court held not, reasoning that the divorce revocation statute was tangential to the purposes of ERISA because the statute "does not alter the nature of the plan itself, the administrator's fiduciary duties, or the requirements for plan administration." 38 The U.S. Supreme Court, in a 7-2 decision authored by Justice Thomas, reversed on the ground that the Washington divorce revocation statute requires the administrator of the ERISA-governed plan to "pay benefits to the beneficiaries chosen by state law, rather than to those identified in the plan document." ${ }^{9}$ Because "this statute governs the payment of benefits, a central matter of plan administration," the Court was unwilling to see the divorce revocation

32. 532 U.S. at 147.

33. ERISA $\S 402(b)(4), 29$ U.S.C. $\$ 1102(b)(4)(2012)$.

34. ERISA $\S 404(a)(1)(D), 29$ U.S.C. $\$ 1104(a)(1)(D)$. The Court in Egelhoff also pointed to ERISA's definition of the term "beneficiary" as someone "designated by a plan participant, or by the terms of [the] plan." 532 U.S. at 147 (quoting ERISA $\S 3(8), 29$ U.S.C. $\$ 1002(8)$ ).

35. ERISA $§ 514(a), 29$ U.S.C. $\$ 1144(a)$.

36. Summarized in LangBein, Pratt \& STABile, supra note 30 , at 830-49.

37. "'[W]e look both to 'the objectives of the ERISA statute as a guide to the scope of the state law that Congress understood would survive,' as well as to the nature of the effect of the state law on ERISA plans." Egelhoff, 532 U.S. at 147 (quoting California Div. of Labor Standards Enforcement v. Dillingham Constr., N. A., 519 U.S. 316, 325 (1997) (quoting New York State Conference of Blue Cross \& Blue Shield Plans v. Travelers Ins. Co., 514 U.S. 645, 656 (1995))). Regarding the place of Egelhoff in the development of the Court's ERISA preemption case law, see Edward A. Zelinsky, Egelhoff, ERISA Preemption, and the Conundrum of the "Relate to" Clause, 91 TAX NOTES 1917 (2001). Zelinsky reads ERISA's broad preemption language as creating a presumption in favor of preemption of state law, contrary to the normal presumption against preemption, but still rebuttable in circumstances in which the state interest is strong and the intrusion on federal interests, if any, is slight.

38. In re Estate of Egelhoff, 989 P.2d 80, 90 (Wash. 1999).

39. Egelhoff, 532 U.S. at 147. 
statute as one "regulating 'areas where ERISA has nothing to say.' "40 Thus, the Court read ERISA to preempt the state law even though ERISA, being wholly silent about divorce revocation, has literally nothing to say about it.

The Court's contention that ERISA "governs the payment of benefits, a central matter of plan administration," deserves careful probing. The question that needs asking is whether ERISA should be treated as governing every aspect of the payment of benefits, including matters about which ERISA is silent, such as interpreting the meaning of beneficiary designations. ERISA is a regulatory statute enacted to protect promised benefits against forfeiture on account of overreaching plan design or plan maladministration. ERISA was not designed to do the interpretive work of state wealth transfer law, that is, to resolve constructional problems concerning the transferor's intent. Such problems abound. Which of two women claiming to be the decedent's widow was his lawful spouse? ${ }^{41}$ Does the word "children" in an ERISAplan beneficiary designation include adopted children, if the plan terms do not so say? ${ }^{42}$ Was the transferor of sound mind when he executed the beneficiary designation, or did he lack capacity on account of illness or duress? ${ }^{43}$ State wealth transfer law addresses such questions. ${ }^{44}$ Justice Breyer, dissenting in Egelhoff (for himself and Justice Stevens), pointed to this dimension of the Washington divorce revocation statute, which he characterized as "a rule of interpretation . . . designed to carry out, not to conflict with, the employee's likely intention as revealed in the plan documents." 45 The beneficiary designations in the plan documents in Egelhoff say, "Pay Donna," but they do not address the question of interpretation that Washington wealth transfer law does address, which is whether the true meaning of that designation is, "Pay Donna, except in the event that Donna and I should be divorced at the time of

40. Id. at 148 (quoting Dillingham, 519 U.S. at 330 ).

41. See, e.g., DaimlerChrysler Corp. Healthcare Benefits Plan v. Durden, 448 F.3d 918 (6th Cir. 2006) (applying Ohio law to ERISA-covered plan); Cent. States, Se. \& Sw. Areas Pension Fund v. Gray, No. 02-CV-8381, 2003 WL 22339272, at *2 (N.D. Ill. Oct. 10, 2003) (applying Texas law to ERISA-covered plan and explaining: "Because there is no federal domestic relations law and marriage and divorce are traditional subjects of state regulation, we must look to state law to determine [which of the two] is the 'surviving spouse' under the Plan." (citation omitted)).

42. See, e.g., Herring v. Campbell, No. 2-09-CV-30-TJW, 2010 WL 2640407 (E.D. Tex. June 30, 2010) (applying Texas law of equitable adoption in an ERISA case, rejecting Egelhoff-based claim of preemption).

43. See, e.g, Tinsley v. Gen. Motors Corp., 227 F.3d 700, 704 (6th Cir. 2000) (holding that federal common law governs claims of fraud and undue influence regarding an ERISA plan beneficiary designation, because ERISA preempts state law).

44. See, e.g., Property Restatement, supra note $11, \S 2.5(2)$ (status of adopted children for purposes of succession); id. $\$ \$ 8.1-8.3$ (2003) (capacity).

45. Egelhoff, 532 U.S. at 154 (Breyer, J., dissenting). 
my death." Justice Breyer emphasized that "whether a designation that (here explicitly) refers to a wife remains valid after divorce" is a question that "[t]he documents themselves do not answer . . . any more than they describe what is to occur in a host of other special circumstances (e.g., mental incompetence, intoxication, ambiguous names, etc.)." 46

Beyond the claim that fidelity to the terms of the two ERISA plan documents required the result in Egelhoff, Justice Thomas offered a functional justification for preempting the Washington divorce revocation statute. He contended that the statute "interferes with nationally uniform plan administration," 47 a value that the Court has viewed as a goal of ERISA preemption. ${ }^{48}$ Preempting state law spares plan administrators from having "to master the relevant laws of 50 states and to contend with litigation" about those laws. ${ }^{49}$ Dissenting, Justice Breyer questioned whether looking up local constructional law was particularly burdensome. He pointed out that plan "administrators have to familiarize themselves with state law in any event when they answer such routine legal questions as whether amounts due are subject to garnishment, who is a 'spouse,' who qualifies as a 'child,' or when an employee is legally dead." 50 In aid of this process of consulting state law, ERISA plans commonly contain a choice of law provision, specifying which state's law governs state-law issues.

In connection with the objective of promoting "nationally uniform" administration of ERISA-covered plans, the Court in Egelhoff expressed concern to spare plan administrators from having to confront "conflicting legal obligations" under different states' laws, for example, in a case in which the ex-spouses live in different states. ${ }^{51}$ Liability risk in such cases is not, however, serious, because a plan faced with uncertainty about the correct rule of law may and routinely does simply interplead in federal court.52 Furthermore, stakeholder protection

\footnotetext{
46. Id. at 156 .

47. Id. at 148 (majority opinion).

48. E.g., Fort Halifax Packing, Inc. v. Coyne, 482 U.S. 1 (1987).

49. Egelhoff, 532 U.S. at 149.

50. Id. at 157. Justice Breyer also pointed out that a plan sponsor wishing to spare the plan from the supposed burden of having to refer to state divorce revocation law could simply impose a divorce revocation rule as a plan term. $I d$.

51. Id. at 149 .

52. Pursuant either to Federal Rule of Civil Procedure 22, or to the federal interpleader statute, 28 U.S.C. $\$ 1335$ (2012). Interpleader actions by ERISA plan stakeholders are quite common; most of the slayer cases discussed infra text accompanying notes 144-46 and 148, were framed as interpleader actions by the insurer or other stakeholder. Indeed, it has been held that failure to interplead can constitute breach of ERISA's fiduciary duty of prudent plan administration, ERISA $\$$ 404(a)(1)(B), 29 U.S.C. 1104(a)(1)(B). See Atwater v. Nortel Networks,
} 
against double payout is a commonplace of state divorce revocation law. The Uniform Probate Code version provides that a payor "is not liable for having made a payment . . . to a beneficiary designated in a governing instrument affected by a divorce... . before the payor ... received written notice of the divorce." 53

In enacting ERISA, Congress could have included a comprehensive body of constructional law to supplant the state laws that normally do the work of interpreting transferors' intent in the wealth transfer field. Congress did not do so. The inference that should have been drawn from ERISA's silence on these matters is that Congress did not intend to displace such state laws, especially in view of "the presumption against preemption in areas of traditional state regulation such as family law,"54 which the Court in Egelhoff acknowledged but refused to follow. The Supreme Court has long deferred to state law on questions of marital status. As the Court explained in a 1956 case applying the state definition of "children" to a question of federal copyright law:

The scope of a federal right is, of course, a federal question, but that does not mean that its content is not to be determined by state, rather than federal law. This is especially true where a statute deals with a familial relationship; there is no federal law of domestic relations, which is primarily a matter of state concern. ${ }^{55}$

ERISA now contains an express provision authorizing the enforcement of state-court marital property decrees issued incident to divorce (called qualified domestic relations orders, or "QDROs") against ERISA-regulated pension accounts. ${ }^{56}$ This measure was added by amendment in $1984,{ }^{57}$ a decade after the initial enactment of ERISA. During the decade during which ERISA was silent on the point, many cases raised the question of whether ERISA's preemption and anti-

388 F. Supp. 2d 610 (M.D.N.C. 2005). For the view that interpleader procedure should be discouraged in ERISA cases because it shifts litigation expenses to plan participants, see Albert Feuer, Determining the Death Beneficiary Under an ERISA Plan and the Rights of Such a Beneficiary, 54 Bloomberg TAX MGMT. Mem. (BNA) No. 323, at 16-19 (2013).

53. UPC $\$ 2-804(\mathrm{~g})(1)$. In such circumstances, the statute recognizes a restitutionary cause of action, rendering the mistakenly paid ex-spouse "personally liable for the amount of the payment . . . to the person who is entitled to it under" the divorce revocation statute. $I d$. $\S 2$ $804(\mathrm{~h})(1)$. The remedy is restitutionary because, under the divorce revocation statute, the exspouse was not entitled to the payment, and hence, even absent $\$ 2-804(\mathrm{~h})(1)$, the payment would be recoverable under the common law of restitution as having been made under mistake of fact or law. See Restatement (THIRD) OF ReSTiTUTION AND UnJUST ENRICHMENT $\$ 6$ (2011) (payment of money not due) \& cmt. $c$ (mistake as to liability).

54. Egelhoff, 532 U.S. at 152.

55. De Sylva v. Ballentine, 351 U.S. 570,580 (1956) (citations omitted).

56. ERISA $\$ 206(d)(3), 29$ U.S.C. $\$ 1056(d)(3)$. The Internal Revenue Code contains a conforming provision. See I.R.C. $\$ 414$ (p) (2012).

57. Retirement Equity Act of 1984, Pub. L. 98-397, 98 Stat. 1426 (1984). 
alienation provisions defeated such state-court decrees. The federal courts all but unanimously enforced the state decrees. ${ }^{58}$ In the 1984 amendment providing for such enforcement, Congress effectively ratified the federal-court consensus against preemption. Thus, in the one circumstance in which Congress faced the choice between preempting or enforcing state domestic relations law against ERISAregulated accounts, Congress chose not to preempt. The QDRO regime pertains to the division of an employee's pension account during his or her lifetime, and thus has had little bearing on beneficiary designations; the QDRO regime does not apply at all to life insurance accounts. Accordingly, the divorce revocation problem at issue in Egelhoff did not come into discussion and was not addressed in the 1984 legislation, but the principle embodied in the QDRO regime-deference to state law on marital property matters incident to divorce-invited extension to state divorce revocation statutes, contrary to the Court's decision in Egelhoff.

By treating ERISA as preempting the state-law solution to a traditional state-law issue, Egelhoff disrespects the longstanding allocation of responsibility between the two legal systems. Divorce revocation is an issue about which federal law provides no direction and expresses no federal interest ("there is no federal law of domestic relations, which is primarily a matter of state concern" ${ }^{59}$ ). By preventing state law from doing its customary work of interpreting the meaning of beneficiary designations, federal preemption needlessly defeats the core policy of wealth transfer law, to implement transferor's intent. ${ }^{60}$ Preemption of state wealth transfer law is quite appropriate in circumstances in which there is a significant federal interest. A notable example of explicit (and principled) federal intervention in family wealth transfer policy was the decision that Congress made in another of its 1984 amendments to ERISA, mandating that certain

58. Regarding the pre-1984 case law and regulatory rulings rejecting defenses based on ERISA's preemption and antialienation provisions, see LANGBEIN, PRATT \& STABILE, supra note 30, at 857-58. The leading case, American Telephone \& Telegraph Co. v. Merry, 592 F.2d 118 (2d Cir. 1979), quoted with approval the view that Judge Weinfeld had expressed in an earlier such case "that the 'generalized proscriptions' of ERISA's anti-alienation and assignment provision and the statute's preemption clause were 'not sufficient to infer that Congress meant to preclude the ancient family law right of maintenance and support and the issuance of process to enforce that right.'" 592 F.2d at 122 (quoting Cartledge v. Miller, 457 F. Supp. 1156 (S.D.N.Y. 1978)).

59. See De Sylva, 351 U.S. at 580 (" $[\mathrm{T}]$ here is no federal law of domestic relations, which is primarily a matter of state concern.").

60. See Property Restatement, supra note $11, \S 10.1$, discussed supra text accompanying note 19 . 
pension annuities provide for minimum spousal shares. ${ }^{61}$ Because ERISA preempts state law relating to pension plans, such a reform could only have been made by means of federal law. In Egelhoff, by contrast (and in Hillman, as discussed next), the preemption of state divorce revocation law was wholly destructive; principled state law was suppressed even though federal law was wholly silent on the issue.

\section{POST-PREEMPTION PREEMPTION}

\section{A. Post-Distribution Relief}

However deficient the reasoning in Egelhoff and however unfortunate the result, the Court's 7-2 decision stands. Accordingly, at the plan or account level, an ERISA-compliant beneficiary designation preempts state divorce revocation law, and by inference, the same principle applies to beneficiary designations in other types of financial accounts that are federally created or regulated. Egelhoff did not, however, address the further question of whether, once the federally regulated account makes payment to the ex-spouse, the person(s) entitled to take under the state divorce revocation statute could recover the payment from the ex-spouse in an action based on state law. Actions of this sort, which have come to be known as "post-distribution" claims, are based on the premise that the purpose of preemption, as voiced in Egelhoff, is to protect against state-law "interfer[ence] with nationally uniform plan administration." 62 Accordingly, once account-level distribution has been made to the person named in the federally regulated beneficiary designation, the federal interest is satisfied, and there is no federal interest in intruding on the operation of state wealth transfer law as regards the ultimate entitlement to the asset.

A decade before Egelhoff, the drafters of the Uniform Probate Code's divorce revocation measure foresaw the risk of ERISA preemption $^{63}$ and undertook to facilitate the post-distribution relief in that event. The Code provides that the ex-spouse who receives the account payment is "personally liable for the amount of the payment ... to the person who would have been entitled to it were [the state divorce revocation statute] not preempted." 64 The theory of such

61. ERISA $\S 205,29$ U.S.C. $\$ 1055$. Regarding the requirement that pension annuities take joint and survivor form, see LANGBEIN, PRATT \& STABILE, supra note 30, at 285-94; WIEDENBECK, supra note 31 , at $250-54$.

62. Egelhoff v. Egelhoff, 532 U.S. 141, 148 (2001).

63. The official comment explains the drafters' concern that ERISA's "extraordinarily broad" preemption clause might result in preemption of state divorce revocationlaw. UPC $\$ 2-804 \mathrm{cmt}$.

64. Id. $\$ 2-804(\mathrm{~h})(2)$ 
post-distribution recovery is restitutionary: an account-level payment has been made for the purpose of federal-level administrative convenience to a person who, as a matter of state wealth transfer law, is not entitled to it, and who should therefore be required to disgorge it to prevent unjust enrichment. ${ }^{65}$ The post-distribution remedy is a statutory version of the ancient equitable remedy of constructive trust, ${ }^{66}$ a type of remedy that the Supreme Court has held in other settings to be authorized under ERISA's enforcement provision for "appropriate equitable relief." 67

In the years after Egelhoff, post-distribution relief was awarded in several cases arising in consequence of ERISA's QDRO regime, previously mentioned, ${ }^{68}$ which allows a state-court marital property decree to be enforced against an ERISA pension account, but subject to the condition that the state decree satisfy certain particulars of content and description designed to ease the burden of compliance for plan administration. ${ }^{69}$ Cases recurrently arise in which a divorcing spouse secures a marital property settlement or state-court decree that purports to govern an ERISA plan account but that neglects to satisfy the QDRO rules and is thus unenforceable against the plan. The Supreme Court dealt with such a case in Kennedy v. Plan Administrator for DuPont Savings \& Investment Plan. ${ }^{70}$ The divorcing couple had agreed to a marital property settlement under which the wife waived her interest in the husband's pension account. He later died without having altered the beneficiary designation on the account that named

65. "If a third person makes a payment to the defendant to which (as between claimant and defendant) the claimant has a better legal or equitable right, the claimant is entitled to restitution from the defendant as necessary to prevent unjust enrichment." RESTATEMENT (THIRD) OF RESTITUTION AND UNJUST ENRICHMENT $§ 48$ (2011).

66. For discussion of the post-distribution remedy in divorce-revocation legislation as imposing a form of statutory constructive trust, see Sarabeth A. Rayho, Note, Divorcees Turn About in Their Graves as Ex-Spouses Cash In: Codified Constructive Trusts Ensure an Equitable Result Regarding ERISA-Governed Employee Benefit Plans, $106 \mathrm{MICH}$. L. REV. 373, 373-97 (2007). As codified in the Restatement, a constructive trust arises when "a defendant is unjustly enriched by the acquisition of title to identifiable property at the expense of the claimant or in violation of the claimant's rights"; in such circumstances, "the defendant may be declared a constructive trustee, for the benefit of the claimant, of the property in question and its traceable product." RESTATEMENT (THIRD) OF RESTITUTION AND UNJUST ENRICHMENT $§ 55(1)$ (2011).

67. ERISA $\$ 502(\mathrm{a})(3)(\mathrm{B}), 29$ U.S.C. $\$ 1132(\mathrm{a})(3)(\mathrm{B})$. In Sereboff v. Mid Atlantic Medical Services, Inc., 547 U.S. 356 (2006), an ERISA-regulated health insurance plan paid medical expenses on behalf of the Sereboffs, who were insured plan participants. The plan contained a subrogation clause entitling the insurer to reimbursement for such payments in the event of a subsequent tort recovery. The Court sustained the insurer's right to "a constructive trust or equitable lien," which the Court called a "familiar rul[e] of equity." "Id. at 364 (citation omitted).

68. Supra notes 56-58 and accompanying text.

69. See ERISA § 206(d)(3), 29 U.S.C. $\$ 1056(d)(3)$; I.R.C. $\$ 414(p), 26$ U.S.C. $\$ 414(p)$.

70. 555 U.S. $285,285-86$ (2009). 
the now-ex-wife as the death beneficiary. The husband's estate claimed the proceeds, relying on her waiver. The Supreme Court held that ERISA required the plan to pay the benefit to the ex-wife "in accordance with the documents and instruments governing the plan."71

The decision in Kennedy resolved the question of the plan's duty to make distribution in accordance with the beneficiary designation, but the Court expressly left open the question, which had not been raised in that case, of post-distribution relief. The Court framed the latter question as "whether the [husband's] Estate could have brought an action in state or federal court against [the ex-wife] to obtain the benefits after they were distributed." 72 In such a case, the husband's estate would be seeking to recover from the ex-wife the amount that she received from the pension account, presumably as the disgorgement remedy to correct for her breach of her state-law-governed agreement to waive her claim to that account.

Just such a claim was raised in Estate of Kensinger v. URL Pharma, Inc. ${ }^{73}$ a Third Circuit case decided in 2012 on facts that the court regarded as "virtually identical to"74 Kennedy. The court held for the husband's estate, reasoning that "to the extent that ERISA is concerned with the expeditious payment of plan proceeds to beneficiaries, permitting suits against beneficiaries after benefits have been paid does not implicate any concern of expeditious payment or undermine any core objective of ERISA." ${ }^{25}$ Kensinger relied upon several state-court opinions holding similarly, including an Oklahoma case explaining that "the pension plan funds were no longer entitled to ERISA protection once the plan funds were distributed." ${ }^{6}$ In Andochick v. Byrd, ${ }^{77}$ a case on "facts nearly identical"78 to Kensinger (and Kennedy), the Fourth Circuit followed Kensinger, concluding that "ERISA does not preempt post-distribution suits against ERISA beneficiaries." 79

71. ERISA $\S 404(a)(1)(D), 29$ U.S.C. $\$ 1104(a)(1)(D)$, cited in Kennedy, 555 U.S. at 300.

72. Kennedy, 555 U.S. at 299 n. 10.

73. 674 F.3d 131, 132-33 (3d Cir. 2012).

74. Id. at 133 .

75. Id. at 137 (emphasis omitted).

76. Id. at 137 (citing Pardee v. Pardee, 112 P.3d 308, 315-16 (Okla. Civ. App. 2004)). The court also cited Alcorn v. Appleton, 708 S.E.2d 390 (Ga. Ct. App. 2011), and Sweebe v. Sweebe, 712 N.W.2d 708 (Mich. 2006). Kensinger, 674 F.3d at 137.

77. 709 F.3d 296 (4th Cir. 2013), cert. denied, 134 S. Ct. 235 (2013).

78. $709 \mathrm{~F} .3 \mathrm{~d}$ at 299 .

79. Id. at 301 . In so deciding, the court thought it was "adopt[ing] the same view as every published appellate opinion to address the question." Id. (citing cases). The court overlooked one contrary decision, Staelens v. Staelens, 677 F. Supp. 2d 499 (D. Mass. 2010); see also McMorrow v. Langevin, No. 10-P-1591, 2011 WL 2436748, at *2 (Mass. App. Ct. June 20, 2011) (endorsing 


\section{B. Hillman}

Three months after the Fourth Circuit decision in Andochick, the Supreme Court decided Hillman v. Maretta, ${ }^{80}$ preempting statelaw-authorized post-distribution relief against an ex-spouse who took under a federally regulated beneficiary designation. Although Hillman was not an ERISA case, the Court's 8-0 opinion will inevitably be treated as governing in ERISA cases as well. Hillman effectively abrogates Kensinger and Andochick, and it will preclude state-lawbased post-distribution relief against the unjustly enriched ex-spouse in any case in which that ex-spouse takes under a federally created or federally regulated beneficiary designation.

Hillman featured garden-variety divorced-beneficiary facts. In 1996 Warren Hillman designated his then-spouse Judy Maretta as the beneficiary of a life insurance policy issued by the Metropolitan Life Insurance Company. Warren and Judy divorced in 1998. In 2002 Warren married Jacqueline Hillman. In 2008 Warren died, having never revised the beneficiary designation naming Judy. These events took place in Virginia, which has a divorce revocation statute that would have struck Judy's interest had Warren purchased his insurance from the Metropolitan in the form of an individual policy. ${ }^{81}$ But Warren, a federal civilian employee, ${ }^{82}$ purchased the insurance under a group policy made available through a program established by a federal statute, the Federal Employees' Group Life Insurance Act ("FEGLIA"). 83 The federal Office of Personnel Management ("OPM") administers FEGLIA beneficiary claims. Warren's ex-spouse Judy, the designated beneficiary, and Jacqueline, Warren's widow, both claimed the policy proceeds. OPM ordered the benefits paid to Judy "because she had been named as the beneficiary." 84

Jacqueline then sued Judy in Virginia state court to recover the proceeds. The parties stipulated that, under existing precedent, the core Virginia divorce revocation statute was preempted. What remained in

Staelens in dicta but finding that the language of the marital property decree in question did not entitle the claimant to the nonprobate account).

80. 133 S. Ct. 1943 (2013).

81. See VA. CODE ANn. \$ 20-111.1(A) (2012).

82. Although the insurance was provided through an employee benefit plan, the plan was ERISA-exempt. See ERISA $§ 4(b), 29$ U.S.C. 1003(b) (excluding governmental plans). In cases involving an ERISA-exempt employee benefit plan that is not otherwise subject to federal preemption, state divorce revocation law applies. See, e.g., Stillman v. TIAA-CREF, 343 F.3d 1311 (10th Cir. 2003), in which the Utah divorce revocation statute was applied to a beneficiary designation in a pension account arising under the ERISA-exempt plan of a state university.

83. 5 U.S.C. $\$ \$ 8701-8716(2012)$.

84. 133 S. Ct. at 1949. 
dispute was a further provision of the Virginia statute, authorizing post-distribution relief in the event of preemption. The statute renders an ex-spouse who receives such a payment "personally liable for the amount of the payment to the person who would have been entitled to it" had the divorce revocation statute not been preempted. ${ }^{85}$ The trial court sustained Jacqueline's action for post-distribution relief, but the Virginia Supreme Court held the measure preempted, and the U.S. Supreme Court affirmed in an opinion by Justice Sotomayor.

Justice Sotomayor took as her starting point the statutory text authorizing the FEGLIA program, which provides that an insured employee's death benefit is to be paid "to the beneficiary ... designated by the employee," or if none survives, to the employee's widow, children, or other relatives in a statutorily prescribed order ${ }^{86}$ that is functionally comparable to a state-law intestacy regime. ${ }^{87}$ To decide the preemption question, the Court saw itself required to discern the purpose ${ }^{88}$ of this language that the death benefit be paid "to the beneficiary ... designated by the employee." The widow who would take under the Virginia post-distribution statute contended (echoing the rationale in Egelhoff) that "Congress' purpose in enacting FEGLIA was to advance administrative convenience by establishing a clear rule to dictate where the Government should direct insurance proceeds." 89 The Court conceded "some force" to this view, and acknowledged that if administrative convenience had been "Congress' only purpose, then there might be no conflict between [the Virginia post-distribution provision] and FEGLIA" because the Virginia "cause of action takes effect only after benefits have been paid." 90 But the Court concluded that administrative convenience was not the sole purpose of the FEGLIA provision. Rather, Congress had the further purpose of seeing to it that "the insurance proceeds will be paid to the named beneficiary and that the beneficiary can use them." 91 This assertion decided the case, by supplying the premise for the Court's decision that Virginia's

85. VA. CODE ANN. \$ 20-111.1(D) (2012).

86. 5 U.S.C. $\$ 8705$ (a), summarized in Hillman, 133 S. Ct. at 1947-48. Like a state intestacy statute, FEGLIA's list of statutory takers is a default regime meant to reflect common intent, applicable only in the circumstance in which the insured has neglected to specify particular primary and contingent beneficiaries.

87. Hillman, $133 \mathrm{~S}$. Ct. at 1947-48. Regarding the patterns of intestate distribution, see PROPERTY RESTATEMENT, supra note $11, \S \S 2.1-2.4$.

88. "This case raises a question of purposes and objectives pre-emption." $133 \mathrm{~S}$. Ct. at 1950.

89. Id

90. Id.

91. Id. at 1953 . 
post-distribution provision “interferes with Congress' objective that insurance proceeds belong to the named beneficiary." 92

Remarkably, the Court was unable to point to any mention of this supposed Congressional "objective" in the statutory text or other legislative materials. Instead, the Court read FEGLIA's silence on the divorce revocation rule as an indication that Congress disfavored the rule. Providing a remedy for divorce revocation, the Court said, was "not the judgment that Congress made. Rather . . . Congress established a clear and predictable procedure for an employee to indicate who the intended beneficiary of his life insurance shall be." 93 In this way, the Court treated the failure of Congress to address a traditional topic of state wealth transfer law as importing a "judgment" that Congress meant to preclude consulting state wealth transfer law when construing the meaning of a beneficiary designation, although federal courts have routinely turned to state constructional law on other questions of marital status arising under FEGLIA. ${ }^{94}$ The far more likely explanation for FEGLIA's silence on divorce revocation is that Congress gave no thought to such routine matters of state wealth transfer law, regarding them as not germane to the officially expressed purpose of FEGLIA, which was "to provide low-cost group life insurance to Federal employees."95

Like ERISA, ${ }^{96}$ FEGLIA contains an express statutory provision, section 8705(e), authorizing the enforcement of state-court marital property decrees issued incident to divorce. ${ }^{97}$ As with ERISA's QDRO regime, section 8705(e) is the one circumstance in which Congress contemplated the effect of divorce on a FEGLIA account, and as in ERISA, Congress chose to defer to state law, not to preempt it. Because the principle underlying section $8705(\mathrm{e})$ is deference to state law on FEGLIA marital property matters arising from divorce, the Supreme Court in Hillman could easily have treated state divorce revocation statutes as falling within that policy. Instead, the Court read the failure of section $8705(\mathrm{e})$ to deal with divorce revocation as evidencing

92. Id. at 1955 .

93. Id. at 1952

94. For example, on the question of which of two claimants was the lawful spouse of a FEGLIA insured, see Metropolitan Life Ins. Co. v. Manning, 568 F.2d 922 (2d Cir. 1977) (applying Connecticut law); Spearman v. Spearman, 482 F.2d 1202 (5th Cir. 1973) (applying California law).

95. H.R. Rep. No. 83-2579, at 1 (2d Sess. 1954), quoted by the Court, 133 S. Ct. at 1947. Regarding the economics of group insurance, see supra note 28. 58 .

96. ERISA $\$ 206(d)(3), 29$ U.S.C. $\$ 1056(d)(3)$, discussed supra text accompanying notes 5697. 5 U.S.C. $\$ 8705(\mathrm{e})$. 
Congressional intent to restrict the measure to its "precise conditions." 98

Justice Thomas, concurring in the result in Hillman, resisted the Court's purported inquiry into the statutory purpose. He saw no need to "look[ beyond the text," because "the ordinary meanings of FEGLIA and [the Virginia post-distribution provision] directly conflict." 99 This attitude toward the work of interpreting governing language exemplifies the "plain meaning" fallacy that Wigmore discredited long ago, and which the Restatement of Property has repudiated for wealth transfer law. ${ }^{100}$ Commenting on the interpretation of documents, Wigmore spoke of the "truth ... that words always need interpretation." 101 What Justice Thomas calls the "ordinary meaning" in this case is the meaning that has been rejected by every American legislature that has considered the question of whether a transferor is likely to have intended a spousal beneficiary designation to remain in effect in the event the parties subsequently divorce. ${ }^{102}$

\section{Wissner and Ridgway}

Why did the Court strain to treat Congress as having addressed a topic about which Congress in fact had been silent? One factor that appears to have motivated the Court was the wish to avoid disturbing two older precedents, Wissner $v$. Wissner, ${ }^{103}$ decided in 1950 , and Ridgway v. Ridgway, ${ }^{104}$ from 1981, cases dealing with beneficiary designations under federal statutes providing life insurance programs for military personnel. In each case, a sharply divided Court "preempted state laws that mandated a different distribution of benefits." 105

\footnotetext{
98. Hillman, $133 \mathrm{~S}$. Ct. at 1953 n.5.

99. Id. at 1955 (Thomas, J., concurring).

100. "The plain-meaning rule is archaic because it unduly stresses a supposed ordinary meaning of the words employed." PROPERTY RESTATEMENT, supra note $11, \$ 10.2 \mathrm{cmt}$. b. Under the Restatement rule, a court may consult evidence of meaning extrinsic to the text of the donative document. In divorce-revocation cases, there commonly is no such evidence, in which case the divorce-revocation rule governs as a rule of construction. See id. $\S 11.3(\mathrm{a})$ ("An ambiguity to which a rule of construction applies is resolved by the rule of construction, unless evidence establishes that the donor had a different intention.").

101. 9 John H. Wigmore, A Treatise on the ANGLo-AMERican System of Evidence in TRIALS AT COMMON LAW $\$ 2470$, at 227 (3d ed. 1940). Regarding the construction of documents, Wigmore wrote that the plain meaning "is simply the meaning of the people who did not write the document." Id. § 2462 , at 191 .

102. Regarding the state statutes, see supra text accompanying notes 11-13, 22-23.

103. 338 U.S. $655,655(1950)$.

104. 454 U.S. 46,46 (1981).

105. Hillman v. Maretta, 133 S. Ct. 1943, 1950 (2013).
} 
In Hillman the Court concluded that Wissner and Ridgway "govern[ed],"106 although neither Wissner nor Ridgway concerned divorce revocation or comparable state constructional law.

In Wissner, the insured, who was killed in military service, had designated his mother as the death beneficiary on the insurance policy. In a California state-court action, his widow claimed a half interest in the proceeds under California community property law on the ground that the insured had purchased the policy from funds that belonged half to her. The California Supreme Court sustained her claim, but the U.S. Supreme Court reversed, in a 5-3 opinion by Justice Clark, holding the widow's claim preempted. The federal statute creating the insurance program provided beneficiary-designation and revocation features of the sort common to virtually all life insurance policies, specifying that the insured "shall have the right to designate the beneficiary or beneficiaries of the insurance . . and shall . . a at all times have the right to change the beneficiary or beneficiaries." 107 The Supreme Court treated these boilerplate designation terms as the basis for holding that the widow's claim was preempted. The Court said that these terms showed that "Congress has spoken with force and clarity in directing that the proceeds belong to the named beneficiary and no other."108 Accordingly, the widow's California community property right had to be preempted because enforcing it would "substitute[ the widow for the mother, who was the beneficiary Congress directed shall receive the insurance money." 109

The Court's phrase, "and no other," would prove to be an influential rhetorical flourish, quoted twice in Ridgway ${ }^{110}$ and again decades later in Hillman, ${ }^{111}$ but it entailed a large and quite unsupported extension of meaning. In state wealth transfer law, where beneficiary designations are routinely encountered and interpreted, they are subjected to constructional principles that sometimes do substitute others. For example, the antilapse statute provides for alternative takers, commonly descendants, in certain circumstances in which the designated beneficiary predeceases the transferor. ${ }^{112}$ Another notable example, discussed further in Part V of this Article, is the slayer

106. "These precedents accordingly govern our analysis of the relationship between [the Virginia post-distribution statute] and FEGLIA in this case." Id. at 1951.

107. National Service Life Insurance Act of 1940, then cited as 38 U.S.C. $\$ 802(\mathrm{~g})$, quoted in Wissner, 338 U.S. at 658.

108. 338 U.S. at 658 (emphasis supplied).

109. 338 U.S. at 659, quoted in Hillman, 133 S. Ct. at 1950.

110. 454 U.S. $46,55-56$ (1981).

111. 133 S. Ct. at 1951.

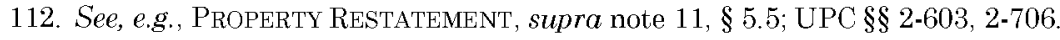


rule, which applies in circumstances in which a transferor is feloniously slain by a person whom the transferor has designated as a devisee or beneficiary. In such cases, state law denies the slayer any benefit by substituting other takers. ${ }^{113}$ Thus, as a description of the effect of beneficiary designation language in then-current American practice, the "no other" remark in Wissner was wrong. If the claim was that Congress meant to depart from that practice, the Court pointed to no evidence of such a divergent meaning.

Dissenting in Wissner for Justices Frankfurter, Jackson, and himself, Justice Minton challenged the majority's reasoning in giving preemptive force to the federal statute's provision for the insured to designate beneficiaries: "Fully to respect the right which Congress gave the serviceman to designate his beneficiary does not require disrespect of settled family law."114 The dissenters would have enforced the widow's state-law right, under which she was "the owner of a half portion of these proceeds because such proceeds are the fruits of funds originally hers" under state law. ${ }^{115}$ Indeed, Justice Minton insisted: "I cannot believe that Congress intended to say to a serviceman, 'You may take your wife's property and purchase a policy of insurance payable to your mother, and we will see that your defrauded wife gets none of the money." "116

In Ridgway the insured serviceman, identified as Sergeant Ridgway, and his wife April were Maine domiciliaries. The couple divorced. The Maine divorce decree included a term ordering the insured to designate his three children as beneficiaries of the life insurance policy and to keep the policy in effect for them. Months after the divorce, Sergeant Ridgway remarried. In violation of the divorce decree, he revised the beneficiary designation on the policy to name Donna, the new wife. ${ }^{117}$ On his death, state-court proceedings ensued. Donna claimed the policy proceeds as designated beneficiary. April, suing on behalf of the three children, sought to have Donna declared a constructive trustee over the proceeds for the children in accord with the divorce decree, a state-law remedy that, as the Maine Supreme

113. See infra text accompanying notes 125-29, 134.

114. 338 U.S. at 663 .

115. Id. at 662 .

116. $I d$. at $663-64$.

117. Sergeant Ridgway did this by "chang[ing] the policy's beneficiary designation to ... direct[] that its proceeds be paid as specified 'by law," "thereby invoking "the statutory order of beneficiary precedence" under which "the policy proceeds, in the event of Ridgway's death, would be paid to his 'widow,' that is, his 'lawful spouse ... at the time of his death." "Ridgway v. Ridgway, 454 U.S. $46,48-49$ (1981) (internal citations omitted). 
Court remarked below, is a commonly granted remedy on such facts. ${ }^{118}$ The insurance carrier under the federal program paid the funds into court.

The Maine Supreme Court held for April, reasoning that the federally authorized beneficiary designation process "does not reflect any federal interest in permitting a serviceman to evade the responsibility to provide for his minor children imposed both by virtue of his voluntary agreement and by the express provision of a valid state court decree." 119 The U.S. Supreme Court reversed in a 6-3 opinion by Justice Blackmun, holding the case "controlled by Wissner." 120 As in Wissner, the main ground of decision was the insured's compliance with beneficiary designation procedures contained in the federal statute that established the insurance program. Dissenting, Justice Stevens responded that " $[\mathrm{t}]$ he right to designate the beneficiary of an insurance policy is a common feature in insurance contracts. It surely is not a right that can be characterized as uniquely federal in any sense." 121 Accordingly, he observed, "the mere fact that the right has its source in a federal statute does not require that it be given a construction different from that given a comparable right created by state law or by private contract." 122

I have emphasized the dissents in Wissner and Ridgway, which appear to me to have been better reasoned, but even if those cases were correctly decided, the Court in Hillman decades later could easily have distinguished both. ${ }^{123}$ Neither Wissner nor Ridgway dealt with the divorce revocation problem. Moreover, the state-law claims asserted in Wissner and Ridgway were not, as is the divorce revocation rule, intent-

118. See Ridgway v. Prudential Ins. Co. of Am., 419 A.2d 1030, 1031 (Me. 1980) (citing state cases). Apparently unaware of the tension with Ridgway, the Sixth Circuit in 2000 applied Michigan law in a similar case involving ERISA-plan insurance benefits, holding "that once the benefits ... have been distributed according to the plan documents, ERISA does not preempt the imposition of a constructive trust on those benefits." Cent. States, Se. \& Sw. Areas Pension Fund v. Howell, 227 F.3d 672, 678-79 (6th Cir. 2000); accord Bd. of Trs. of the Ind. State Council of Plasters \& Cement Masons Pension Fund v. Sheline, No. 1:12-CV-447, 2013 WL 408812, at *2 (W.D. Mich. Jan. 31, 2013) (affirming the holding in Howell). Regarding the constructive trust as an equitable remedy, see supra text accompanying notes $65-67$.

119. Ridgway, 419 A.2d at 1035, quoted in Ridgway, 454 U.S. at 53.

120. 454 U.S. at 55.

121. Id. at 67 .

122. Id.

123. Another ground of distinction, which was argued to the Court in Hillman, was that the federal statutes in Wissner and Ridgway, unlike that in Hillman, contained express antiattachment provisions restricting the enforcement of third-party claims. The Court brusquely dismissed "[t]hese discussions of the anti-attachment provisions" as "alternative grounds to support the judgment in each case, and not necessary components of the holdings." $133 \mathrm{~S}$. Ct. 1943, 1954 (2013). 
implementing rules of construction. ${ }^{124}$ Rather, the claim in each was intent-defeating - that a state-created right, arising prior to the time that the insured executed the beneficiary designation, should prevail against the insured's expression of intent in the federally authorized beneficiary designation. In both Wissner and Ridgway, the transferor intended to benefit the persons he designated. The premise of the divorce revocation statutes that the Court preempted in Egelhoff and Hillman is that the transferor does not wish to benefit the designated beneficiary when divorce has supervened.

\section{THE SLAYER BENEFICIARY AND THE IMPUlSE TO FEDERAL COMMON LAW}

A pervasive feature of state wealth transfer law is the rule forbidding the beneficiary who feloniously ${ }^{125}$ slays the transferor from taking any benefit under a will or nonprobate beneficiary designation naming the slayer. ${ }^{126}$ The slayer rule is codified in the Restatements of Property ${ }^{127}$ and Restitution, ${ }^{128}$ and in the Uniform Probate Code. ${ }^{129}$ (The Code's slayer provisions are closely modeled on its divorce revocation rule, making comparable arrangements for post-distribution relief in the event of federal preemption, ${ }^{130}$ and for protecting the insurer or other stakeholder who makes good faith payment to the slayer, unaware of the slayer's wrongdoing. ${ }^{131}$ ) The slayer rule is largely intent-implementing in effect because the transferor would seldom want his or her slayer to benefit. Nevertheless, the rule is mandatory. The transferor is forbidden to countermand it, ${ }^{132}$ because the rule

124. Regarding the intent-implementing character of the divorce-revocation rule, see supra text accompanying notes $14-18$.

125. Regarding the intent standard, the relation between civil and criminal liability in slayer cases, and the corresponding evidentiary requirements, see PROPERTY RESTATEMENT, supra note $11, \S 8.4(\mathrm{~b})$, cmts. d-h.

126. Citations to state statutes are collected, $i d . \S 8.4$ reporter's note 1.

127. Id. $\$ 8.4$.

128. Restatement (ThiRd) of Restitution And UnJust EnRichment $§ 45$ (2011) (slayer rule); see also id. $\$ 3$ ("A person is not permitted to profit by his own wrong.").

129. UPC \& $2-803$.

130. Id. $\S 2-803(\mathrm{i})(2)$. The official comment to the subsection explains that the provision is meant to function in the event of ERISA preemption. $I d$. cmt.

131. Id. $\$ 2-803(\mathrm{i})(1)$.

132. Compare, for example, the Uniform Probate Code divorce-revocation rule, UPC $\$ 2-804(\mathrm{~b})$, which commences with a proviso permitting contraindication ("Except as provided by the express terms of a governing instrument ..."), with UPC $\$ 2-803($ b), the slayer rule, which contains no such term. In two states, Wisconsin and Louisiana, the slayer statutes do allow the transferor to countermand the rule. See Jesse Dukeminier \& Robert H. Sitkoff, Wills, Trusts and Estates 137 (9th ed. 2013), discussing Wis. STAT. \$ 854.14(6)(b) (2012); and LA. Civ. CodE ANN. arts. 941, 943, 945 (permitting "reconciliation with or forgiveness by the decedent" to defeat the slayer rule). 
enforces an overriding principle of public policy that the law will not assist a wrongdoer to profit from the wrong. ${ }^{133}$

Neither ERISA nor FEGLIA, the federal statutes that were held to preempt state wealth transfer law in Egelhoff and Hillman respectively, addresses the slayer problem, even though slayer cases are sadly common ${ }^{134}$ (further evidence that Congress had no interest in disturbing the preexisting system of wealth transfer law when making provision for federally created or regulated beneficiary designations). Because the statutes are silent, under the literalist reasoning in Egelhoff and Hillman the designated beneficiary who slays an ERISA or FEGLIA insured would stand to collect the insurance proceeds. Recall the justification that Justice Thomas offered for preempting the state divorce revocation statute in Egelhoff-that the statute impermissibly requires the administrator of the ERISA-governed plan to "pay benefits to the beneficiaries chosen by state law, rather than to those identified in the plan documents." 135 That is exactly what a state slayer statute does. Similarly, in Hillman, the rationale for denying effect to Virginia's post-distribution divorce revocation remedy was that it "interferes with Congress' objective that insurance proceeds belong to the named beneficiary." 136 So does the Virginia slayer statute. Hillman repeated the line from Wissner that Congress has "direct[ed] that the proceeds belong to the named beneficiary and no other." ${ }^{37}$ The slayer statutes, however, always award the proceeds to someone other than the slayer.

Justice Breyer's dissent in Egelhoff pointed out that divorce revocation statutes are "virtually indistinguishable" from slayer statutes, because both " 'gover[n] the payment of benefits, a central matter of plan administration." "138 This objection was unanswerable,

133. This point is discussed in Property Restatement, supra note $11, \S 8.4 \mathrm{cmt}$. B (1999).

134. The vast case law is collected in Michael G. Walsh, Annotation, Homicide as Precluding Taking under Will or by Intestacy, 25 A.L.R.4th 787 (1983); and F. S. Tinio, Annotation, Killing of Insured by Beneficiary as Affecting Life Insurance or Its Proceeds, 27 A.L.R.3d 794 (1969). "In 2011, in incidents of murder for which the relationships of murder victims and offenders were known, . . 24.8 percent of victims were slain by family members . . . Of the female murder victims for whom the relationships to their offenders were known, 36.5 percent were murdered by their husbands or boyfriends." Federal Bureau of Investigation, Crime in the United States, 2011, Expanded Homicide Data, UNIFORM CRIME REPORTS (Sept. 2012), available at http:// www.fbi.gov/about-us/cjis/ucr/crime-in-the-u. s/2011/crime-in-the-u.s.-2011/offenses-known-tolaw-enforcement/expanded/expanded-homicide-data, archived at http://perma.cc/BK8R-XM4W

135. 532 U.S. 141,147 (2001).

136. 133 S. Ct. 1943,1955 (2013).

137. Id. at 1951 (quoting Wissner v. Wissner, 338 U.S. 655, $658(1950)$ ).

138. Egelhoff, 532 U.S. at 159-60, quoting the majority, id. at 148. Justice Breyer's position is developed in Katherine A. McAllister, Note, A Distinction Without a Difference? ERISA 
and the Court largely refused to engage with it. The slayer statutes "are not before us," said Justice Thomas in reply, "so we do not decide the issue." ${ }^{139}$ As dictum, however, he observed that because slayer statutes are so common and "more or less uniform" among the states, "their interference with the aims of ERISA is at least debatable." 140 In truth, there is considerable variety in the provisions of state slayer statutes, ${ }^{141}$ whereas divorce revocation statutes are much more uniform. Moreover, even had Justice Thomas been correct in thinking that the state slayer statutes are "more or less uniform," he would still have had no answer to the point that state slayer statutes, like state divorce revocation statutes, require the plan to do precisely what Justice Thomas in Egelhoff said that ERISA forbids-"pay benefits to the beneficiaries chosen by state law, rather than to those identified in the plan documents." 142

The Supreme Court long ago endorsed the policy merits of the slayer rule, saying that "[i]t would be a reproach to the jurisprudence of the country if one could recover insurance money payable on the death of a party whose life he had feloniously taken." ${ }^{143}$ Federal courts faced with ERISA slayer cases before Egelhoff applied state slayer statutes. ${ }^{144}$ Likewise, federal courts have applied state slayer law in

Preemption and the Untenable Differential Treatment of Revocation-on-Divorce and Slayer Statutes, 52 B.C. L. REV. 1481, 1483-1513 (2011).

139. Egelhoff, 532 U.S. at 152. In Kennedy, the Court again refused to consider the tension with slayer statutes. 555 U.S. 285, 304 n. 14 (2009). The issue was also raised in Ridgway, in which the majority refused to engage with it. See 454 U.S. 46,60 n.9 (1981) ("Our ruling on a situation of that kind is reserved for another day."). In Egelhoff, immediately preceding the language quoted in text, Justice Thomas summarized the argument based on the state slayer statutes, that "[i]n the ERISA context, these 'slayer' statutes could revoke the beneficiary status of someone who murdered a plan participant." 532 U.S. at 152 . Some courts have read this language of summary as meaning to endorse nonpreemption of state slayer statutes. See, e.g., Nale v. Ford Motor Co. UAW Retirement Plan, 703 F. Supp. 2d 714, 722 (E.D. Mich 2010) (reasoning that the Court's silence "suggest[s] that ERISA would not preempt state slayer statutes"); and cases cited infra note 148. That interpretation is not supportable, however, because of the Court's insistence in the next sentence that "[t]hose statutes are not before us, so we do not decide the issue." Egelhoff, 532 U.S. at 152 .

140. Id.

141. Among the issues on which the slayer statutes diverge is the extent to which they reach all nonprobate transfers; how they treat joint tenancies; the preclusive effect of criminal conviction, especially for less culpable forms of homicide; and whether the slayer's descendants are also prevented from taking. For discussion, see DUKEMINIER \& SiTKOFF, supra note 132, at 137-38; and Albert Feuer, Who Is Entitled to Benefits from ERISA Plans?, 40 J. MARSHALL L. ReV. 919, $1049-50$ (2007).

142. 532 U.S. at 147.

143. Mut. Life Ins. Co. v. Armstrong, 117 U.S. 591, 600 (1886) (federal common law before Erie R.R. v. Tompkins, 304 U.S. 64 (1938)).

144. The first reported case, Mendez-Bellido v. Board of Trustees of Division 1181, A.T. U New York Employees Pension Fund \& Plan, held that "a state law prohibiting a killer from profiting from her crime is not preempted by ERISA.” 709 F. Supp. 329, 331 (E.D.N.Y. 1989) (applying New 
FEGLIA cases. ${ }^{145}$ In some of these cases, the courts remarked that even if the state law were preempted, federal common law would have supplied an alternative ground of decision. ${ }^{146}$ The Supreme Court has in other settings recognized the need for the courts "to develop a 'federal common law of rights and obligations under ERISA-regulated plans.' "147 Following Egelhoff it has become common in slayer cases to invoke both grounds ${ }^{148}$ or to rest the result solely on federal common law. ${ }^{149}$ In 2011 the Department of Veterans Affairs promulgated a slayer rule for federal military insurance programs, ${ }^{150}$ which the

York law). "This common law rule is rooted in public policy and has broad application to insurance policies, wills and intestacy." Id. Mendez-Bellido was followed in Administrative Committee for the H.E.B. Investment \& Retirement Plan v. Harris, 217 F. Supp. 2d 759, 761 (E.D. Tex. 2002) (applying Texas slayer law but noting as an alternative ground that federal common law would apply); New Orleans Electrical Pension Fund v. Newman, 784 F. Supp. 1233, 1236 (E.D. La. 1992) (applying Louisiana slayer law); and New Orleans Electrical Pension Fund v. DeRocha, 779 F. Supp. 845, $849-51$ (E.D. La. 1991) (finding Louisiana slayer law not preempted but observing as an alternative ground that federal common law would apply). A post-Egelhoff case applying state slayer law to an ERISA-governed insurance plan is First National Bank \& Trust Co. of Mountain Home v. Stonebridge Life Insurance Co., 619 F.3d 951, 955 (8th Cir. 2010) (applying Arkansas law).

145. E.g., Metro. Life Ins. Co. v. Rupe, 908 F.2d 977 (9th Cir. 1990) (unpublished table decision) (applying California slayer law). In Metropolitan Life Insurance Co. v. White, the court applied Texas slayer law but said that federal common law would supply an alternative ground. 972 F.2d 122, 124 (5th Cir. 1992), cert. denied sub nom. Yohey v. Metro. Life Ins. Co., 507 U.S. 977 (1993). 51.

146. White, 972 F.2d at 124; Harris, 217 F. Supp. 2d at 761-62; DeRocha, 779 F. Supp. at $849-$

147. Firestone Tire \& Rubber Co. v. Bruch, 489 U.S. 101, 110 (1989) (citation omitted), endorsed in Mertens v. Hewitt Associates, 508 U.S. 248, 259 (1993). See generally Jeffrey A. Brauch, The Federal Common Law of ERISA, 21 HARV. J.L. \& PUB. POL'Y 541, 542-604 (1998) (surveying case law as of 1998).

148. "Since Egelhoff, several district courts considering this issue have reasoned that, based on the dicta in Egelhoff," discussed supra note 139, "it is likely that ERISA does not preempt state slayer statues, but that it is unnecessary to determine the preemption issue since federal common law provides the same result as a slayer statute." Honeywell Sav. \& Ownership Plan v. Jicha, No. 08-4265 (DRD), 2010 WL 276237, at *5 (D.N.J. 2010); accord Estate of Burklund v. Burklund (In re Estate of Burklund), No. 11-5024, 2013 WL 327622, at *5-6 (E.D. Pa. 2013). One court declined to "address the question of whether federal common law or the law of some state supplies the rule of decision," because "[t]he law seems to be the same virtually everywhere and thus there is no conflict." Metro. Life Ins. Co. v. Little, No. 13-CV-1059 (BMC), 2013 WL 4495684, at *3 n.4 (E.D.N.Y. Aug. 17, 2013).

149. E.g., Ahmed v. Ahmed, 817 N.E.2d 424, 429 (Ohio Ct. App. 2004) (ERISA case), discussed in Peter S. Lin, Murdering the Slayer Statute Under the Pretense of ERISA Preemption: Ahmed v. Ahmed, 58 TAX L. 767, 772-79 (2005); Prudential Ins. Co. v. Tolbert, 320 F. Supp. 2d 1378, 138082 (S.D. Ga. 2004) (applying federal common law to a slayer case arising under the federal insurance program that was at issue in Ridgway). Regarding the place of the doctrine in the law of federal jurisdiction, see Jay Tidmarsh \& Brian J. Murray, A Theory of Federal Common Law, $100 \mathrm{Nw}$. U. L. REV. 585 (2006). As regards ERISA, the Supreme Court has read the legislative history to say that Congress "expect[ed]" that the federal courts would develop "a federal common law of rights and obligations under ERISA-regulated plans." Pilot Life Ins. Co. v. Dedeaux, 481 U.S. 41, 56 (1987).

150. 38 C.F.R. $\$ 9.5(\mathrm{e})(2014)$. 
Department described as "[t]he Federal common-law slayer's rule." 151 No reported ERISA or FEGLIA case has ever allowed the slayer to take. ${ }^{152}$

The Supreme Court has yet to rule on the slayer problem in beneficiary designation cases arising under federally created or federally regulated wealth transfer regimes such as ERISA or FEGLIA. There is no reason to think that the Court will allow slayers to profit from homicide in the name of federal preemption. Either the Court will decline to preempt state slayer law, or the Court will develop a slayer rule as federal common law. Neither solution is consistent with the Wissner-derived rationale of Hillman, that wealth passing under a federally regulated beneficiary designation "belong[s] to the named beneficiary and no other." 153 The more likely choice is federal common law, which aligns with Egelhoffs emphasis on the efficiency of "nationally uniform plan administration." 154 Federalization permits but does not assure uniformity because, unless and until the Supreme Court (or Congress) does the federalizing, disagreements can form among the federal courts about whether and what to federalize. ${ }^{155}$

The trend toward a federal common law slayer rule invites the question, why not also preserve the divorce revocation rule as federal common law? To be sure, the slayer rule has a moral imperative more pronounced than the intent-implementing policy of the divorce revocation rule. Both rules share the common purpose of preventing

151. Servicemembers' Group Life Insurance and Veterans' Group Life Insurance-Slayer's Rule Exclusion, 76 Fed. Reg. 77,455, 77,455 (Dec. 13, 2011).

152. For an extreme literalist view of the reach of ERISA's requirement that plan benefits be distributed "in accordance with the documents and instruments governing the plan," ERISA $\S$ 404(a)(1)(D), 29 U.S.C. $§ 1104(a)(1)(D)$, see Feuer, supra note 141, at 1048-59, arguing that ERISA not only preempts state slayer laws but also precludes federal common law, hence that the slayer must be allowed to take under an ERISA-covered benefit designation. For the view that the slayer rule should not apply in cases in which the slayer had suffered severe domestic abuse at the hands of the victim, or in cases in which the slayer's conduct resulted in material part from mental illness, see Carla Spivack, Killers Shouldn't Inherit from Their Victims-Or Should They?, 48 GA. L. REV. 145, 215-226 (2013).

153. Hillman v. Maretta, 133 S. Ct. 1943, 1951 (2013) (emphasis omitted) (quoting Wissner v. Wissner, 338 U.S. 655 , $658(1950)$ ).

154. Egelhoff v. Egelhoff ex rel. Breiner, 532 U.S. 141, 148 (2001).

155. Commentators have suggested that in the wealth transfer field, such problems can be minimized by looking to the provisions of the PROPERTY RESTATEMENT, supra note 11, and the Uniform Probate Code as models. See, e.g., David S. Lebolt, Making the Best of Egelhoff: Federal Common Law for ERISA-Preempted Beneficiary Designations, 28 J. PENSION PLAN. \& COMPLIANCE, 29, 51-54 (Fall 2002); accord T.P. Gallanis, ERISA and the Law of Succession, 65 OHIO ST. L.J. 185, 195-96 (2004). For the view that following Restatement rules "further[s] the interest in achieving uniformity in the articulation of federal common law," see United States v. Alcan Aluminum Corp., 964 F.2d 252, 268 (3d Cir. 1992) (applying joint and several liability standards from the Restatement (Second) of Torts as the common law of a federal environmental statute). 
unjust enrichment. As previously noticed, ${ }^{156}$ the divorce revocation rule is an uncontested principle of state wealth transfer law, in the sense that no state probate code that addresses the problem chooses a contrary rule. Compared to Egelhoff and Hillman, which defeat the divorce revocation rule, a federal common law rule that enforces the divorce revocation principle would surely be preferable.

Supplanting state wealth transfer law with duplicative federal common law is a technique that has no natural stopping point, and in the wake of Egelhoff and Hillman, the pressure to create more federal common law will increase. It is, however, a mistake to assume that federal common law responds effectively to the concern (which was the Supreme Court's ostensible rationale for preempting the divorce revocation statute in Egelhoff) that state law "interferes with nationally uniform plan administration." 157 Differences among the federal courts about how to formulate federal common law on a particular point can arise and remain unresolved for long years. ${ }^{158}$ Although the Supreme Court in Egelhoff justified preemption on the ground of sparing plan administrators from having "to master the relevant laws of 50 states," 159 in practice looking up local law on a point will often be easier than trying to decide which strand of federal common law might find favor with the particular federal court that reviews the plan's decision.

Another means of federalizing traditionally state-law rules such as divorce revocation or the slayer rule is for the sponsors of federally created or federally regulated plans to incorporate these rules as plan terms. In the ERISA setting, the employer or other plan sponsor has broad discretion over the content of plan terms. ${ }^{160}$ The Internal Revenue Service, which, together with the Department of Labor, has regulatory authority over ERISA, ${ }^{161}$ has recently expressed its view that a pension plan's terms may provide that in the event that a participant becomes divorced, the "designation of [the] former spouse as

156. See supra notes $14-18$ and accompanying text.

157. Egelhoff, 532 U.S. at 148.

158. See, for example, Waggoner's account of how federal courts have differed in deciding which state slayer laws to consult in devising federal common law on wealth transfer issues. Lawrence W. Waggoner, The Creeping Federalization of Wealth-Transfer Law, 67 VAND. L. REV. $1635,1649-51$ (2014).

159. 532 U.S. at 149.

160. See Curtiss-Wright Corp. v. Schoonejongen, 514 U.S. 73, 78 (1995) (holding that "[e]mployers or other plan sponsors are generally free under ERISA, for any reason at any time, to adopt, modify, or terminate welfare plans"). The holding was extended to ERISA-covered pension plans in Lockheed Corp. v. Spink, 517 U.S. 882, 890 (1996).

161. Regarding the division of responsibility for ERISA between the IRS and the Department of Labor, see LANGBEIN, PRATT \& STABILE, supra note 30, at 96-97. 
plan beneficiary is automatically revoked." 162 It would be open to either agency to require that ERISA-covered pension and insurance plans adopt such a term. ${ }^{163}$

\section{CONCLUSION}

In recent decades the process of wealth transfer on death has undergone a profound transformation. The older probate system of court-supervised transfer has been increasingly displaced by a nonprobate system in which financial intermediaries (including banks, insurers, mutual funds, and pension plans) transfer the owner's account balance on death. Beneficiary designations on financial accounts tend ever more to do the work of family wealth transmission that used to be done in the probate process.

In the United States, wealth transfer, like other components of family and property law, is prevailingly state law. Indeed, the federal courts have a long tradition of deferring to state probate administration in cases that would otherwise come within the scope of federal jurisdiction. ${ }^{164}$ Although the dominant purpose of wealth transfer lawimplementing transferor's intent ${ }^{165}$ - is straightforward, the field is nevertheless large and complex. ${ }^{166}$ Human affairs are complex, human foresight is limited, and many persons who draft instruments of transfer are inexpert. In consequence, the courts and the legislatures have accreted over the centuries a body of constructional principles and situation-specific constructional rules ${ }^{167}$ that are meant to implement the transferor's intent in cases in which the instrument of transfer is silent or ambiguous on the point. This body of constructional law, which originated in the law of wills, has been extended in recent decades to

162. I.R.S., Employee Plan News, Issue 2013-3 (Sept. 13, 2013), available at www.irs.gov/pub/irs-tege/epn_2013_3.pdf, archived at http:/perma.cc/DZ6K-T88D. In this vein, see Moran's suggestion "to provide in the plan document that upon a participant's divorce, any beneficiary designation forms will be invalid ...." Anne E. Moran, Stuck in the Middle, A Cautionary Tale about Beneficiary Designation Forms, 34 EMP. REL. L.J. Spring 2009, at 70, 73.

163. For an exercise of regulatory authority somewhat comparable to the action of the Department of Veteran Affairs in mandating a slayer rule for federal military insurance programs, see supra text accompanying notes $150-51$.

164. Regarding the probate exception to federal jurisdiction, see 13E CHARLES ALAN WRIGHT \& Arthur Miller, Federal Practice \& Procedure $\$ \$ 3609$, 3610, at 381-96, 423-64 (2009 \& Supp. 2014). See also James E. Pfander \& Michael J.T. Downey, In Search of the Probate Exception, 67 VAND. L. REV. 1533 (2014).

165. See supra text accompanying note 19.

166. E.g., the immense set of constructional rules arising from problems of class gift terminology, regarding which see PROPERTY RESTATEMENT, supra note 11, \$§ 13.1-16.3.

167. See id. $\$ \S 11.1-11.3$. 
nonprobate transfers, in response to the nonprobate revolution. ${ }^{168}$ Much of the work of unifying the law of probate and nonprobate transfers has taken place under the careful deliberative processes of the Uniform Law Commission and the American Law Institute. ${ }^{169}$ The Washington and Virginia divorce revocation statutes at issue in Egelhoff and Hillman exemplify this trend. There is reason to think that these constructional principles are even more important when applied to nonprobate transfers than to wills, because the beneficiary designation forms required under the account terms of many financial intermediaries restrict the ability of a transferor to impose conditions, ${ }^{170}$ such as (for divorce revocation) "to Mary Smith if she and I are then still married."

Because wealth transfer law is prevailingly state law, federal legislation and federal courts have played virtually no role in the project of unifying the law of probate and nonprobate transfers. Indeed, federal courts are sometimes unaware of basic principles of the wealth transfer field, as in Hillman, in which both the majority opinion ${ }^{171}$ and a concurrence by Justice Alito ${ }^{172}$ voice the mistaken assumption that a life insurance beneficiary designation can be altered by will. ${ }^{173}$ Unfamiliarity with basic principles of trust law has been a recurrent

168. See supra text accompanying notes $11,13$.

169. Regarding the role of the uniform laws and the restatements, see, e.g., Langbein, supra note 6; John H. Langbein, Why Did Trust Law Become Statute Law in the United States?, 58 ALA. L. REV. 1069, 1079-81 (2007); Edward C. Halbach, Uniform Acts, Restatements, and Trends in American Trust Law at Century's End, 88 CALIF. L. REV. 1877, 1883-88 (2000); John H. Langbein \& Lawrence W. Waggoner, Reforming the Law of Gratuitous Transfers: The New Uniform Probate Code, 55 ALB. L. REV. 871, 872-90 (1992). Regarding the pervasive influence of the state trust and estate bars in the state-level enactment of legislation in the field, see Langbein, supra note 6 , at $5-7$.

170. A point emphasized in Sterk \& Leslie, supra note 9, at 213-15.

171. Hillman v. Maretta, 133 S. Ct. 1943, 1952 (2013) ("[A] legislature might have reasonably believed that an employee's will is more reliable evidence of his intent than a beneficiary designation form executed years earlier.").

172. Id. at 1957 (Alito, J., concurring) (asserting that the Virginia divorce-revocation statute would pertain "even if the insured manifests a clear contrary intent, such as by providing specifically in a recent will that the proceeds are to go to another party").

173. For the rule against altering a life insurance beneficiary designation by will, see, for example, McCarthy v. Aetra Life Ins. Co., 704 N.E. 2d 557, 560 (N.Y. 1998); Cook v. Equitable Life Assurance Soc., 428 N.E. 2d 110, 116 (Ind. App. 1981). Cases are collected in Wanda Ellen Wakefield, Annotation, Effectiveness of Change of Named Beneficiary of Life or Accident Insurance Policy by Will, 25 A.L.R.4th 1164, 1164-78 (1983 \& Supp.). For bank account beneficiary designations, the rule against revocation by will is codified in UPC\$ 2-613(b). For criticism of the rule, see PROPERTy ReStatement, supra note $11, \$ 7.2$, cmt. e. An ERISA plan document can trump the rule. E.g., Liberty Life Assurance Co. v. Kennedy, 358 F.3d 1295, 1300, 1302 (11th Cir. 2004). 
theme of the Supreme Court's troubled ERISA case law. ${ }^{174}$ Hillman evidences comparable unfamiliarity with basic principles of restitution and unjust enrichment.

Perhaps the most disquieting dimension of the decisions in Egelhoff and Hillman is the Court's disinterest in the purpose of the state-law rule that the two decisions suppressed. In neither case did the Court confront the intent-implementing rationale of the divorce revocation rule, a purpose that is wholly congruent with the regulatory objectives of ERISA, and with FEGLIA's mission to provide federal employees with low-cost group life insurance. The Court's disinterest in the purpose of the divorce revocation rule also meant that the Court had no understanding of the magnitude of the harm that preempting the rule would cause. Egelhoff and Hillman work at cross purposes to one of the most important policy objectives of state legislation and decisional law in the wealth transfer field over the past generation, the movement to unify the constructional law of probate and nonprobate transfers. Just when state wealth transfer law has largely succeeded in developing constructional rules that overcome the probate/nonprobate division, the Supreme Court has opened a new and pointless division between state and federally regulated nonprobate accounts. In consequence of Egelhoff and Hillman, functionally identical transfers must be treated oppositely. The divorce revocation rule continues to apply to the probate estate of a Virginia resident such as Warren Hillman, and to any Metropolitan Life policy that he may have purchased individually, but not to the functionally identical Metropolitan Life policy that he purchased through the FEGLIA program, or that he might have purchased through the ERISAregulated plan of a private employer. Needless to say, the Court in Egelhoff and Hillman did not and could not justify this result.

174. See John H. Langbein, What ERISA Means by "Equitable": The Supreme Court's Trail of Error in Russell, Mertens, and Great-West, 103 CoLUM. L. REV. 1317, 1338-60 (2003); John H. Langbein, The Supreme Court Flunks Trusts, 1990 SUP. CT. REV. 207, 217-23 (1991). 